\title{
Cervical osteomyelitis and an epidural abscess: an unusual form of cat-scratch disease in one case
}

\author{
Hamid Khay ${ }^{1 *}$ (D) Salvatore Chibbaro ${ }^{2}$, Younes Dehneh ${ }^{1}$, Helene Cebula ${ }^{2}$ and François Proust ${ }^{2}$
}

\begin{abstract}
Background: The association of cervical osteomyelitis with epidural abscess is extremely rare; atypical symptomatology is what makes diagnosing and management challenging. This case is the sixth case reported in the literature. The objective of our study is to describe the clinical manifestation and treatment approach.

Case presentation: A 71-year-old male with no medical history, who was admitted to the emergency room for C7-T1 spinal cord compression caused by Bartonella henselae, marked improvement after decompression by evacuating the empyema and antibiotic course.

Conclusion: Cat-scratch disease or subacute regional lymphadenitis is a bacterial infection caused by Bartonella henselae; children and adolescents are mostly infected. Systemic complications are rare; the prevalence of bone damage is estimated at 0.1 to $0.3 \%$. Our case allows a literature review of and put in focus on our diagnostic and therapeutic attitude.
\end{abstract}

Keywords: Case report, Bartonella henselae, Osteomyelitis, Cat-scratch disease, Epidural abscess, Cervical mini-discectomy

\section{Background}

Cat-scratch disease is a bacterial infection of Bartonella henselae. Bartonella henselae is a small Gramnegative bacillus. Cats are healthy carriers, but they can be infected too, cat-to-cat transmission mainly via flea bites or flea dirt; the bacteria reach the oral cavity then to the coat and the claws of the cat during cat's bathing or when fighting with another cat. The germ spread to people if a person get scratched or bitten by infected cat [1].

Children and adolescents are most affected by this infection since adults represent only $10 \%$ of the population according to Carithers $(p=0.007)$ and the average age is 9 years $[2,3]$. Systemic complications are rare; according to Graveleau, the prevalence of bone damage is estimated at 0.1 to $0.3 \%$ [4]. Fever and solitary or regional lymphadenopathy are the classic

\footnotetext{
* Correspondence: hamid.khay@hotmail.fr

'Department of Neurosurgery, Mohammed VI University Hospital, BP 4806

Oujda University, 60049 Oujda, Morocco

Full list of author information is available at the end of the article
}

symptoms associated with a history of cat scratch or bite. In bone involvement, the clinical symptomatology is marked by bone pain $(89 \%)$ and fever $(84 \%)$ [4, $5]$. We report an atypical case: the clinical manifestation and treatment approach.

\section{Case presentation}

We report a case of a 71-year-old male, immunocompetence, with no medical history who presented for several weeks neuropathic pain of the right shoulder associated with hypoesthesia and paresthesias of the ulnar edge of the forearm and last three fingers of the hand as well as night sweats without fever, no spinal pain, or lymphadenopathy. Interrogation reveals cat scratch in early December with purulent discharge for a few days. A strength force deficit was found in $\mathrm{C} 7$ and $\mathrm{C} 8$, counted $3 / 5$. CBC shows leukocytosis at $12 \mathrm{G} / \mathrm{L}$ and an increased $\mathrm{C}$-reactive protein at $120 \mathrm{mg} / \mathrm{l}$. Urine culture performed on was sterile with leukocytes counting $1000 / \mathrm{ml}$. B. henselae serology is IgM and IgG positive. Thoracoabdomino-pelvic CT scan and a transthoracic 
echography were normal. A cervical MRI showed signs of C7-T1 spondylitis associated with an epidural abscess, resulting in spinal cord compression (Fig. 1).

A microsurgical management was performed via the anterior sub axial approach; patient had beneficed of cervicotomy, without sternoclavicular joint removal to reach this level anteriorly. A mini-discectomy, collection drainage, and decompression of the foramina C7T1 were performed. Yellowish purulent semiliquid material was drained. No implant was placed. PCR on the biopsy finds a bone infection with Bartonella henselae.

Medical management by introduction of probabilistic antibiotic therapy with cefotaxime-oflocet. Changing the antibiotic regime to azithromycin-rifampicin for a total period of 6 weeks. The outcome was favorable with gradually deficit recovery. The post-operative MRI, performed 1 day after surgery, showed a complete evacuation of the empyema with persistent bone signal (Fig. 2).

\section{Discussion}

Bartonella osteomyelitis with spinal cord injury remains rare [5, 6]. In a cohort study of 1200 patients with cat-scratch disease, only six patients had systemic complications, $5 \%$ of the population, and among the complications there were only 2 cases of osteomyelitis
$(0.27 \%)[3,5]$. According to the literature, only 5 cases of cervical osteomyelitis have been reported and the present case is the 6th case (Table 1). It is common in children and adolescents. In Bartonella osteomyelitis, the infection spreads to the bone via tow pathways hematogeneous pathway or via lymphatic route $[7,8]$. Thoracic and lumbar vertebras are the mostly affected $(42 \%)$ then cervical vertebras, more rarely, the pelvic girdle (about 11\%), rib cage, femur, humerus, and the head $[9,10]$.

Presence of an epidural abscess associated with osteomyelitis was noted in only 6 cases [7, 10-13].

The diagnosis was made by clinical context, confirmed by clinical examination and a combination of $B$. henselae serology with PCR. These combinations of PCR and serology have great interest in the event of diagnostic difficulties or atypical forms of cat-scratch disease [6, 14-17].

According to Bergmans [18], the diagnosis of CSD is established in the presence of the following criteria:

- Contact with a cat and clinically a scratch or other injury caused by canine aggression.

- A positive skin test

- Absence of other causes of lymphadenitis

- Characteristic histopathology on samples of local or systemic lesions

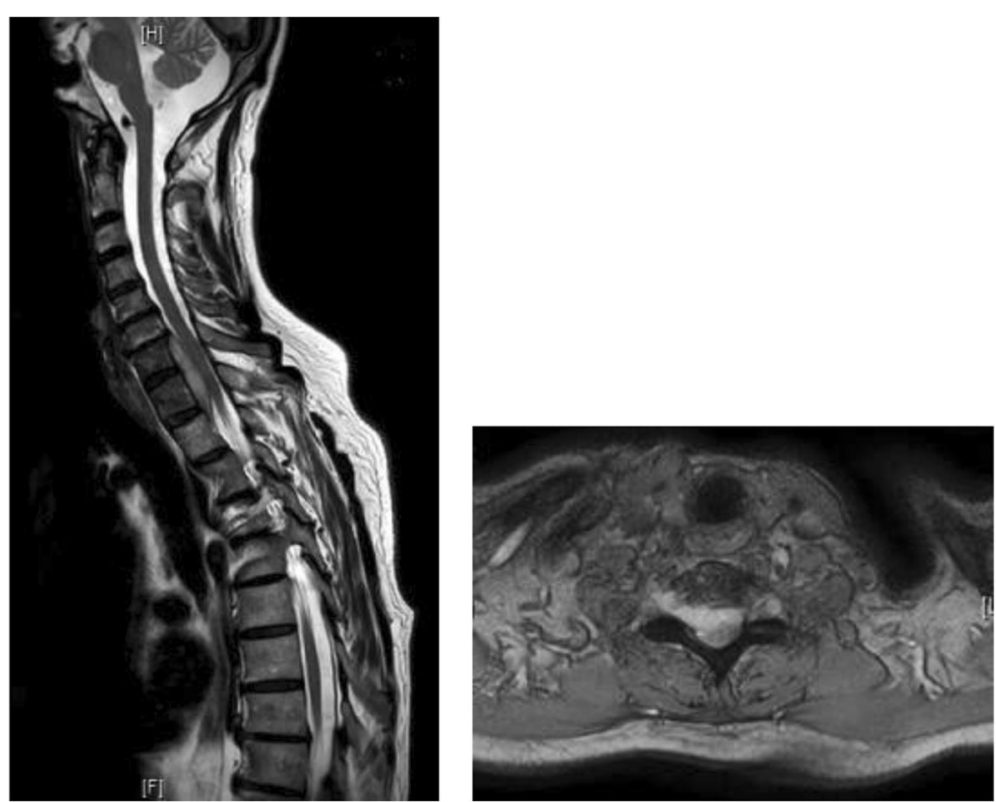

Fig. 1 Sagittal (left) and axial (right) MR images of the cervico-thoracic spine revealing abnormal contrast enhancement of the C6, C7, and T1 vertebral bodies, consistent with osteomyelitis. Additionally, an epidural abscess posterior to the C6-T1 vertebral bodies caused minimal thecal sac compression 


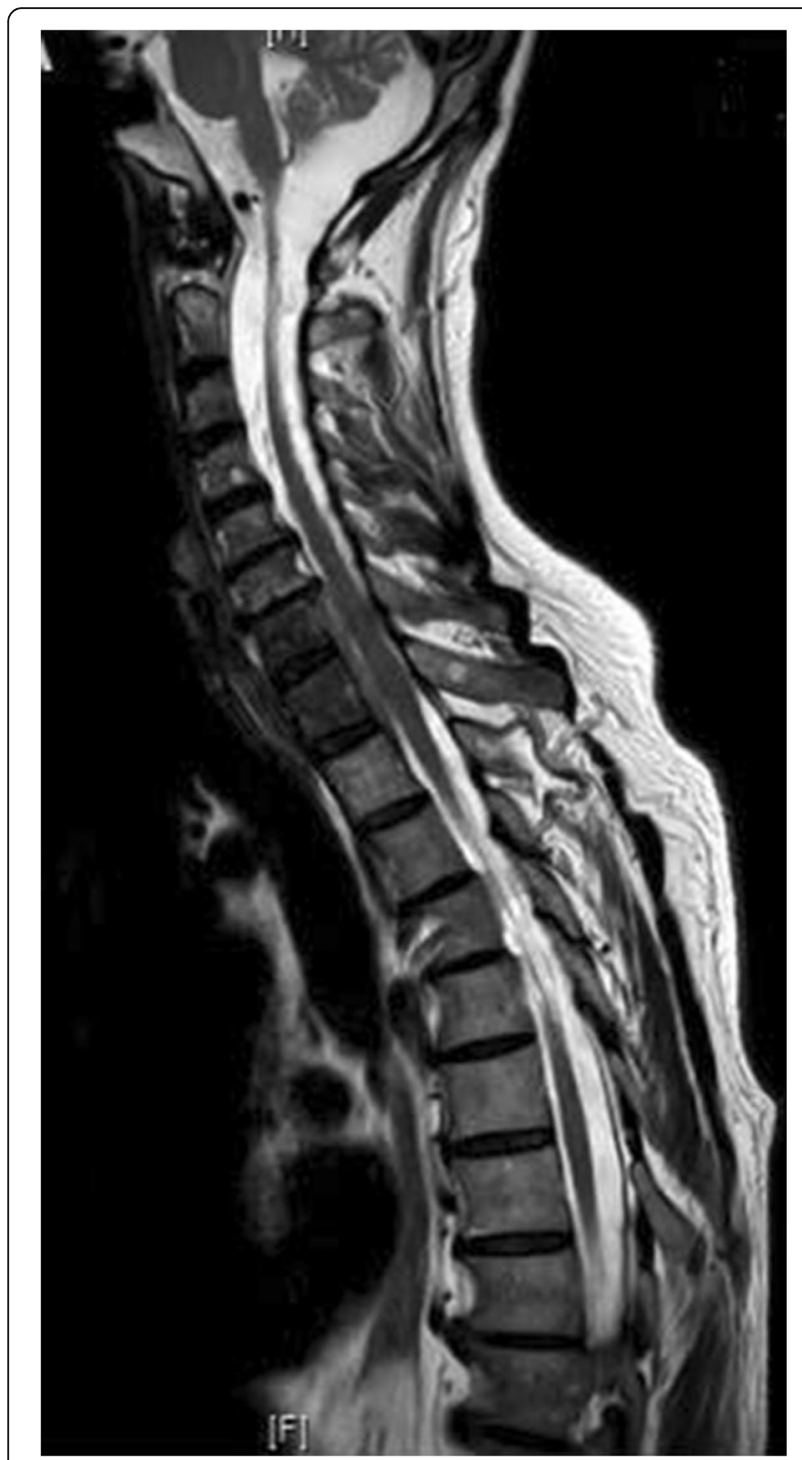

Fig. 2 Sagittal posttreatment MR image of the cervico-thoracic spine, 1 day after surgery, demonstrating persistent enhancement of the $\mathrm{C} 6, \mathrm{C} 7$, and $\mathrm{T} 1$ vertebral bodies and complete resolution of the previously identified epidural abscess
The non-specific clinical presentation, the difficulty in bacteriological diagnosis on the culture of samples, and often the unavailability of intradermal skin tests, are the disadvantages of these criteria. Currently, the diagnosis of certainty is based on the combination of serological and molecular techniques. This diagnostic combination is particularly useful in the context of adults because of the lack of symptoms and diversified differential diagnosis $[5,7,15,16,19]$.

In addition of CSD criteria, we found that spinal pain associated with fever and elevated inflammatory markers, prompt us to search for CSD $[5,9,12]$.
Spinal MRI is the choice examination for a relevant exploration of bone, disk, and spinal injuries. MRI allows physicians to diagnose infection early before bone destruction becomes visible on radiographs or even CT. It also allows a therapeutic evaluation $[5,7$, $11]$.

Therapeutic options, in case of isolated spinal injury, without signs of spinal instability or neurological deficit, include a simple bone or lymph node biopsy. Drainage of the epidural abscess is performed out by the posterior or anterior approach. A surgical treatment, allowing drainage of the abscess with the necessary bacteriological and histopathological samples, without putting up an arthrodesis system is better. In the pediatric population, the laminotomy is sufficient to drain the abscess [10-14, 20].

The medical treatment combines always an antibiotic therapy with a variable duration according to the surgeons, but it varies between 3 weeks and 6 months with an average of 9.9 weeks. The criteria for therapeutic success or failure vary according to the authors, and they include clinical criteria (disappearance of fever, regression of lymphadenopathy, improvement of bone pain, and other signs depending on the disease), biological (infectious and inflammatory assessment), and radiological (regression of radiological lesions) $[3,5,7,19]$.

CSD remains a largely underestimated disease and it can go unnoticed if the patient is mildly symptomatic or if the initial diagnosis is incorrect. Until now, no diagnostic and therapeutic consensus has been established $[5,7,19]$.

Surgical treatment for osteomyelitis should be as less aggressive as possible, followed by efficient antibiotic treatment to achieve better results. In our case, surgical treatment has enabled decompression in emergencies by a 2 to $3 \mathrm{~mm}$, median mini-discectomy with drainage of the abscess. To our knowledge, this is the first case of osteomyelitis treated like this.

\section{Conclusions}

Vertebral osteomyelitis of cervical spine is an atypical and rare complication of cat-scratch disease. The diagnosis is evoked in front of a suspect clinical context and confirmed by the Bartonella henselae serology with a PCR complement on biopsy samples.

Mini-discectomy may be an alternative treatment option especially on extensive osteomyelitis.

No consensus is currently established to unify the management of CSD. We report a rare case of cervical osteomyelitis to describe our particular diagnostic and therapeutic attitude. 
Table 1 Reported cases of cervical spine osteomyelitis secondary to the cat-scratch disease

\begin{tabular}{|c|c|c|c|c|c|c|c|c|c|c|c|c|}
\hline Authors & Year & $\begin{array}{l}\text { Age } \\
\text { (years), } \\
\text { sex }\end{array}$ & Clinic & Fever & $\begin{array}{l}\text { WBC/ } \\
\text { ESR/CRP } \\
\text { elevation }\end{array}$ & Level & Diagnosis & $\begin{array}{l}\text { Epidural } \\
\text { involvement }\end{array}$ & Surgery & $\begin{array}{l}\text { Antibiotic } \\
\text { duration }\end{array}$ & $\begin{array}{l}\text { Recurrence } \\
\text { treatment }\end{array}$ & $\begin{array}{l}\text { Follow- } \\
\text { up }\end{array}$ \\
\hline $\begin{array}{l}\text { Woestyn } \\
\text { et al. }\end{array}$ & 2003 & $62, F$ & $\begin{array}{l}\text { Neck pain, } \\
\text { paresthesia }\end{array}$ & $Y^{*}$ & $\mathrm{Y} / \mathrm{NR}^{*} / \mathrm{Y}$ & C5-6 & $\begin{array}{l}\text { lgGt, } \\
\text { PCR+ }\end{array}$ & $N R$ & $\begin{array}{l}\text { C5-6 } \\
\text { discectomy } \\
\text { and } \\
\text { arthrodesis }\end{array}$ & 6 months & Y, drainage & $\begin{array}{l}9 \\
\text { months }\end{array}$ \\
\hline $\begin{array}{l}\text { Vermeulen } \\
\text { et al. }\end{array}$ & 2006 & $9, F$ & $\begin{array}{l}\text { Neck pain, } \\
\text { torticollis, } \\
\text { delayed } \\
\text { right arm } \\
\text { paresis }\end{array}$ & Y & $Y / Y / Y$ & C4-6 & $\begin{array}{l}\operatorname{lgM}+, \\
\lg G+, P C R \\
+\end{array}$ & $\mathrm{N}^{*}$ & $\begin{array}{l}\text { Anterior open } \\
\text { biopsy and } \\
\text { drain age }\end{array}$ & 3 weeks & N & $\begin{array}{l}3 \\
\text { months }\end{array}$ \\
\hline $\begin{array}{l}\text { Tasher } \\
\text { et al. }\end{array}$ & 2009 & $5, M$ & $\begin{array}{l}\text { Neck pain, } \\
\text { torticollis }\end{array}$ & Y & Y/Y/N & $\begin{array}{l}\text { Skull } \\
\text { base } \\
\text { to C6 }\end{array}$ & $\lg M+$ & Y & $\begin{array}{l}\text { C3-5 } \\
\text { laminectomy } \\
\text { and abscess } \\
\text { drainage }\end{array}$ & 10 weeks & N & $\begin{array}{l}9 \\
\text { weeks }\end{array}$ \\
\hline $\begin{array}{l}\text { Mirouse } \\
\text { et al. }\end{array}$ & 2015 & $14, M$ & $\begin{array}{l}\text { Neck pain, } \\
\text { torticollis }\end{array}$ & Y & $\mathrm{Y} / \mathrm{NR} / \mathrm{Y}$ & C2 & Serology+ & $N$ & $\begin{array}{l}\text { Traction, } \\
\text { surgical } \\
\text { drainage }\end{array}$ & 10 weeks & N & $\begin{array}{l}3 \\
\text { months }\end{array}$ \\
\hline $\begin{array}{l}\text { Akbari } \\
\text { et al. }\end{array}$ & 2018 & $7, M$ & Neck mass & $N$ & $\mathrm{~N} / \mathrm{Y} / \mathrm{NT} T^{*}$ & $C 2-4$ & $\operatorname{lgG}+$ & Y & None, collar & 6 weeks & N & $\begin{array}{l}12 \\
\text { months }\end{array}$ \\
\hline $\begin{array}{l}\text { Present } \\
\text { case }\end{array}$ & 2020 & $71, M$ & $\begin{array}{l}\text { Neck pain, } \\
\text { paresthesia, } \\
\text { motor } \\
\text { deficit C7- } \\
\text { C8 }\end{array}$ & $N$ & Y/NR/Y & $\begin{array}{l}\text { C7- } \\
\text { T1 }\end{array}$ & $\begin{array}{l}\operatorname{lgM}+ \\
\operatorname{lgG}+ \\
\text { PCR+ }\end{array}$ & Y & $\begin{array}{l}\text { C7-8 } \\
\text { discectomy, } \\
\text { arthrodesis, } \\
\text { and abscess } \\
\text { drainage }\end{array}$ & 6 weeks & N & $\begin{array}{l}12 \\
\text { months }\end{array}$ \\
\hline
\end{tabular}

${ }^{*} N$, no (not present); ${ }^{*} N R$, not reported; ${ }^{*} N T$, not tested; ${ }^{*} Y$, yes (present); ${ }^{*}+$, positive

\section{Abbreviations}

B. henselae: Bartonella henselae; $\mathrm{CBC}$ : Complete blood count; IgM: Immunoglobulin M; IgG: Immunoglobulin G; CT scan: Computerized tomography scan; MRI: Magnetic resonance imaging; PCR: Polymerase chain reaction; CSD: Cat-scratch disease

\section{Acknowledgements}

None.

\section{Authors' contributions}

Conception and design: HK, SC. Acquisition of data: HK, SC. Analysis and interpretation of data: HK, SC. Drafting the article: HK, YD. Critically revising the article: all authors. Reviewed submitted version of manuscript: HK, SC, $\mathrm{HC}$, and FP. Approved the final version of the manuscript on behalf of all authors: all authors. Study supervision: FP. "All authors have read and approved the manuscript."

\section{Funding}

None.

Availability of data and materials

Not applicable.

\section{Declarations}

Ethics approval and consent to participate

Not applicable.

\section{Consent for publication}

A written consent to publish this information was obtained from study participants. A proof of consent to publish from study participants can be requested.

\section{Competing interests}

The authors declare that they have no competing interests.

\section{Author details}

${ }^{1}$ Department of Neurosurgery, Mohammed VI University Hospital, BP 4806 Oujda University, 60049 Oujda, Morocco. ${ }^{2}$ Department of Neurosurgery, Hôpital de Hautepierre, Strasbourg, France.

Received: 16 May 2020 Accepted: 3 July 2021

Published online: 18 October 2021

\section{References}

1. Gilliaux O, Ghilain V, van der Linden D, et al. Atypical cat-scratch disease in children: report of seven presentations ranging from hepatosplenic disease to Horner syndrome. Arch Pediatr Infect Dis. 2016;4(1). https://doi.org/10. 5812/pedinfect.28272

2. Peltola H, Pääkkönen M. Acute osteomyelitis in children. N Engl J Med. 2014;370(4):352-60. https://doi.org/10.1056/NEJMra1213956.

3. Carithers HA. Cat-scratch disease. An overview based on a study of 1,200 patients. Am J Dis Child 1960. 1985;139(11):1124-33. https://doi.org/10.1 001/archpedi.1985.02140130062031.

4. Graveleau J, Grossi O, Lefebvre M, Redon H, Caignon JM, Pallardy A, et al. Vertebral osteomyelitis: an unusual presentation of Bartonella henselae infection. Semin Arthritis Rheum. 2011;41(3):511-6. https://doi.org/10.1016/j. semarthrit.2011.04.011

5. Hajjaji N, Hocqueloux L, Kerdraon R, Bret L. Bone infection in cat-scratch disease: a review of the literature. J Infect. 2007;54(5):417-21. https://doi. org/10.1016/j.jinf.2006.10.045.

6. Ridder-Schröter R, Marx A, Beer M, Tappe D, Kreth H-W, Girschick HJ. Abscess-forming lymphadenopathy and osteomyelitis in children with Bartonella henselae infection. J Med Microbiol. 2008;57(4):519-24. https:// doi.org/10.1099/jmm.0.47438-0.

7. Vermeulen MJ, Rutten GJ, Verhagen I, Peeters MF, van Dijken PJ. Transient paresis associated with cat-scratch disease: case report and literature review of vertebral osteomyelitis caused by Bartonella henselae. Pediatr Infect Dis J. 2006;25(12):1177-81. https://doi.org/10.1097/01.inf.0000246807.14916.d3.

8. Anderson BE, Neuman MA. Bartonella spp. as emerging human pathogens. Clin Microbiol Rev. 1997;10(2):203-19. https://doi.org/10.1128/CMR.10.2.203.

9. Zellali K, Benard E, Smokvina E, Belgaid A, Labbé F, Bertrand V. Multifocal pelvic osteomyelitis in a child associated with cat-scratch disease: a case 
report and review of the literature. Paediatr Int Child Health. 2019;39(4):2903. https://doi.org/10.1080/20469047.2018.1476304.

10. Mirouse G, Journe A, Casabianca L, Moreau PE, Pannier S, Glorion C. Bartonella henselae osteoarthritis of the upper cervical spine in a 14-yearold boy. Orthop Traumatol Surg Res. 2015;101(4):519-22. https://doi.org/10.1 016/j.otsr.2015.02.007.

11. Akbari SHA, Averill CE, Roland JL, Orscheln R, Strahle J. Bartonella henselae infection presenting as cervical spine osteomyelitis: case report. J Neurosurg Pediatr. 2018;22(2):189-94. https://doi.org/10.3171/2018.2.PEDS17600.

12. Tasher D, Armarnik E, Mizrahi A, Liat BS, Constantini S, Grisaru-Soen G. Cat scratch disease with cervical vertebral osteomyelitis and spinal epidural abscess. Pediatr Infect Dis J. 2009;28(9):848-50. https://doi.org/10.1097/INF. 0b013e3181a3242e.

13. Woestyn S, Moreau M, Munting E, Bigaignon G, Delmée M. Osteomyelitis caused by Bartonella henselae genotype I in an immunocompetent adult woman. J Clin Microbiol. 2003;41(7):3430-2. https://doi.org/10.1128/jcm.41. 7.3430-3432.2003.

14. Abdel-Haq N, Abuhammour W, Al-Tatari H, Asmar B. Disseminated cat scratch disease with vertebral osteomyelitis and epidural abscess. South Med J. 2005;98(11):1142+.

15. Herremans M, Vermeulen MJ, Van de Kassteele J, Bakker J, Schellekens JFP, Koopmans MPG. The use of Bartonella henselae-specific age dependent lgG and IgM in diagnostic models to discriminate diseased from non-diseased in cat scratch disease serology. J Microbiol Methods. 2007;71(2):107-13. https://doi.org/10.1016/.j.mimet.2007.09.004.

16. Scott MA, McCurley TL, Vnencak-Jones CL, Hager C, McCoy J, Anderson B, et al. Cat scratch disease: detection of Bartonella henselae DNA in archival biopsies from patients with clinically, serologically, and histologically defined disease. Am J Pathol. 1996;149(6):2161-7.

17. Dusser P, Eyssette-Guerreau S, Koné-Paut I. Ostéomyélite dans la maladie des griffes du chat : à propos d'un cas et revue de la littérature. Arch Pédiatrie. 2013;20(6):624-8. https://doi.org/10.1016/j.arcped.2013.03.013.

18. Bergmans AM, Groothedde JW, Schellekens JF, van Embden JD, Ossewaarde JM, Schouls LM. Etiology of cat scratch disease: comparison of polymerase chain reaction detection of Bartonella (formerly Rochalimaea) and Afipia felis DNA with serology and skin tests. J Infect Dis. 1995;171(4):916-23. https://doi.org/10.1093/infdis/171.4.916

19. Johnson SC, Kosut J, Ching N. Disseminated cat scratch disease in pediatric patients in Hawai'i. Hawaii J Health Soc Welf. 2020;79(5 Suppl 1):64-70.

20. Dornbos D, Morin J, Watson JR, Pindrik J. Thoracic osteomyelitis and epidural abscess formation due to cat scratch disease: case report. J Neurosurg Pediatr. 2016;18(6):713-6. https://doi.org/10.3171/2016.7.PEDS1 677.

\section{Publisher's Note}

Springer Nature remains neutral with regard to jurisdictional claims in published maps and institutional affiliations.

\section{Submit your manuscript to a SpringerOpen ${ }^{\circ}$ journal and benefit from:}

- Convenient online submission

- Rigorous peer review

- Open access: articles freely available online

- High visibility within the field

- Retaining the copyright to your article

Submit your next manuscript at $\boldsymbol{\nabla}$ springeropen.com 